\title{
Description of mating behavior, life cycle, and antennal sensilla of Cyclocephala putrida Burmeister, 1847 (Coleoptera, Scarabaeidae, Dynastinae)
}

\author{
Fabíola Gonzaga Saldanha $^{I}$, Sérgio Roberto Rodrigues ${ }^{1 *}$, Ricardo Aparecido Amaro ${ }^{I}$ \& Juares Fuhrmann ${ }^{2}$ \\ ${ }^{1}$ Universidade Estadual de Mato Grosso do Sul, Rodovia MS, 306, km 6,4, Cassilândia, MS, Brasil. \\ ${ }^{2}$ Universidade de São Paulo, Museu de Zoologia, São Paulo, SP, Brasil. \\ *Corresponding author: Sérgio Roberto Rodrigues,e-mail: sergio@uems.br
}

SALDANHA, F.G., RODRIGUES, S.R., AMARO, R.A., FUHRMANN, J. Description of mating behavior, life cycle, and antennal sensilla of Cyclocephala putrida Burmeister, 1847 (Coleoptera, Scarabaeidae, Dynastinae). Biota Neotropica 20(3): e20200973. https://doi.org/10.1590/1676-0611-BN-2020-0973

\begin{abstract}
The genus Cyclocephala is common in Brazil (Coleoptera, Scarabaeidae, Dynastinae). The adults of some species are important pollinators, and the larvae develop in the soil, feed on organic matter, and contribute to nutrient cycle, but immatures of some species feed on plant roots, and some were registered causing damage in crops. The mating process of some phytophagous scarab beetles has a chemical recognition step, and the antenna is the main structure involved in the detection of odorants associated with insect communication. In the present study the mating behavior, life cycle, and antennal sensilla of $C$. putrida are described. The study was conducted at the Universidade Estadual de Mato Grosso do Sul, Cassilândia, Brazil. Adults were collected by a light trap installed from January 2016 to December 2017 and were taken to the laboratory for studies. Adults swarms are brief and were registered from January to February, and specimens were mostly collected at 20:00 to 22:00h. Chemical recognition may occur at least during one of the mating steps, during which the couple kept their antennae moving and the lamellae open, while females select males. In laboratory, the mating process lasted 7.5 minutes on average. The antennae of females have about 3399 sensilla and males about 4229 sensilla. Sensilla placodea types I, II, and III are the most abundant, and sensilla ampullacea, basiconica, and coeloconica are also present. The embryonic period lasted 16.0 days; first, second and third instars lasted 16.0, 48.3, and 165.3 days, respectively. The pupal period lasted 24.0 days. The period between egg deposition and adult emergency is about 271.5 days.
\end{abstract}

Keywords: Chemical Communication, Chemical Receptors, Cyclocephalini, Neotropical, Swarming Flights.

\section{Descrição do comportamento de cópula, ciclo de vida e sensilas antenais de Cyclocephala putrida Burmeister, 1847 (Coleoptera, Scarabaeidae, Dynastinae)}

Resumo: O gênero Cyclocephala é comum no Brasil (Coleoptera, Scarabaeidae, Dynastinae). Os adultos de algumas espécies são importantes polinizadores, e a larva desenvolve-se no solo, alimenta-se de matéria orgânica e contribui para a ciclagem de nutrientes, mas imaturos de algumas espécies alimentam-se de raízes de plantas, e alguns são registrados causando danos em plantas cultivadas. O processo de cópula de algumas espécies de Scarabaeidae fitófagos, apresentam reconhecimento químico, e nas antenas aparecem várias estruturas responsáveis pela detecção dos odores envolvidos na comunicação. No presente trabalho o comportamento de cópula, ciclo de vida e sensilas antenais de Cyclocephala putrida são descritos. O estudo foi conduzido na Universidade Estadual de Mato Grosso do Sul, Cassilândia, Brasil. Adultos foram coletados com armadilha luminosa instalada de Janeiro de 2016 a Dezembro de 2017, e levados para laboratório para estudos. Os adultos revoam por curto período de janeiro a fevereiro, e os espécimes foram coletados em maior quantidade das 20:00 às 22:00 h. O reconhecimento químico possivelmente ocorre durante as etapas que envolvem o comportamento de cópula, no qual o casal mantém as antenas em movimento e as lamelas abertas e as fêmeas selecionam os machos. Em laboratório a cópula dura 7,5 minutos em média. As antenas das fêmeas possuem 3399 sensilas e os machos 4229 sensilas, e as sensilas placódeas dos tipos I, II e III, foram as mais abundantes e sensilas ampuláceas, basicônicas e coelocônicas também estão presentes. O estágio de ovo durou 16,0 dias; o primeiro, segundo e terceiro instar duraram 16,0, 48,3 e 165,3 dias, respectivamente. O período pupal durou 24,0 dias. O período entre deposição dos ovos e emergência dos adultos é de 271,5 dias em média.

Palavras-chave: Comunicação Química, Receptores Químicos, Cyclocephalini, Neotropical, Período De Voo. 


\section{Introduction}

The genus Cyclocephala Dejean, 1821 (Coleoptera, Scarabaeidae, Dynastinae, Cyclocephalini) is distributed through the Americas, and about 123 species have been recorded in Brazil (Grossi \& Vaz-deMello 2019).

Several adults were registered as flower visitors, with potential to be pollinators, and the visited plants are usually used as feeding and mating sites (Moore \& Jameson 2013). Adults of Cyclocephala forsteri Endrödi, 1963 have been associated with flowers of Acrocomia aculeata Lodd. ex Mart. ("macaúba" Arecaceae) (Oliveira \& Ávila 2011), while adults of Cyclocephala melanocephala (Fabricius, 1775) have been found in flowers of Cereus peruvianus (L.) Mill. (Cactaceae) (Silva \& Sazima 1995), sunflowers ("girassol”, Helianthus annuus L., Asteraceae) (Camargo \& Amabile 2001), and passion-fruit flowers ("maracujazeiro", Passiflora edulis Sims, Passifloraceae) (Dias \& Rodrigues 2018). Cyclocephala literata Burmeister, 1847 consumes flowers of Magnolia ovata Spreng. (Magnoliaceae) and uses the plant as a mating site (Gottsberger et al. 2012). Cyclocephala celata Dechambre, 1980 and Cyclocephala cearae Höhne, 1923 have been associated with Taccarum ulei Engl. \& K. Krause (Araceae) plants and their adults were observed feeding and copulating on its flowers (Maia et al. 2013). It is known that some phytophagous scarab beetles locate plants by detecting volatile odorants using the sensilla on their antennae (Anomala cuprea Motschulsky, 1854; Larsson et al. 2001), and the same may occur for Cyclocephalini beetles (Barbosa \& Rodrigues 2016; Maia et al. 2013).

Some Scarabaeidae species release sexual pheromones to chemical recognition, and females select males before copulation (e.g. Facundo et al. 1999, Rodrigues et al. 2014). As well as plant volatiles, insect structures involved in detecting pheromones are antennal sensilla, which are mainly distributed on the surface of lamellae (e.g. Leal \& Mochizuki 1993, Kim \& Leal 2000).

Before copulation, females return to the soil for egg deposition, and their biological cycle varies with species. The time between egg deposition and adult emergence is about 229 days for $C$. verticalis Burmeister, 1847 (Rodrigues et al. 2010), about 164 days for $C$. celata (Souza et al. 2014), and about 108 days for C. distincta Burmeister, 1847 (Souza et al. 2015).

The larvae of Cyclocephala use soil with organic matter as food, therefore being important for nutrient cycling such as C.paraguayensis Arrow, 1913 (Albuquerque et al. 2014). On the other hand, these larvae may consume plant roots, and some species can cause damage to crops such as $C$. forsteri which has been reported as potential pest to soybean crops ("soja", Glycine max (L.) Merr, Fabaceae) (Santos \& Ávila 2007), or such as Cyclocephala flavipennis Arrow, 1914, which has been registered damaging pastures (Duchini et al. 2017).

Although studies have been conducted on Cyclocephala putrida Burmeister, 1847 biology in Cassilândia, state of Mato Grosso do Sul (Brazil), little information is known for this species. Cherman et al. (2014) found larvae of the species in cultivated and non-cultivated areas in the state of Rio Grande do Sul (Brazil), and Bonivardo et al. (2015) reported immatures associated with pasture and maize ("milho", Zea mays L., Poaceae) in Argentine.

Regarding the above-mentioned biological and economic importance of the genus Cyclocephala, the present work aims to describe the mating behavior, the antennal sensilla, and life cycle of $C$. putrida.

\section{Material and Methods}

The study was conducted at the Universidade Estadual de Mato Grosso do Sul (UEMS), Campus of Cassilândia, MS (1906' 48”' S; $51^{\circ} 44^{\prime} 03$ ' W). Sampling and rearing procedures, as well as analysis strategies, were modifications of Rodrigues et al. (2008, 2010).

Adults of C. putrida were collected using a light trap model "Luiz de Queiroz" from January 2016 to December 2017. The trap was installed in a pasture area (Urochloa decumbens Stapf cv Basilisk, Poaceae) and was turned on daily at 18:00 and turned off at 6:00 of the next day. The insects were collected every 60 minutes, and collected adults were sexed by observing male dilated protarsomeres (Figure 1), and couples were placed in $500 \mathrm{~mL}$ plastic containers with half-filled with the same soil from where adults were collected. The adults were reared with slices of bananas (fruit of Musa sp., Musaceae) as food source (see Ferreira et al. 2016). Each couple was observed from February 2016 to February 2017 to behavior observations.

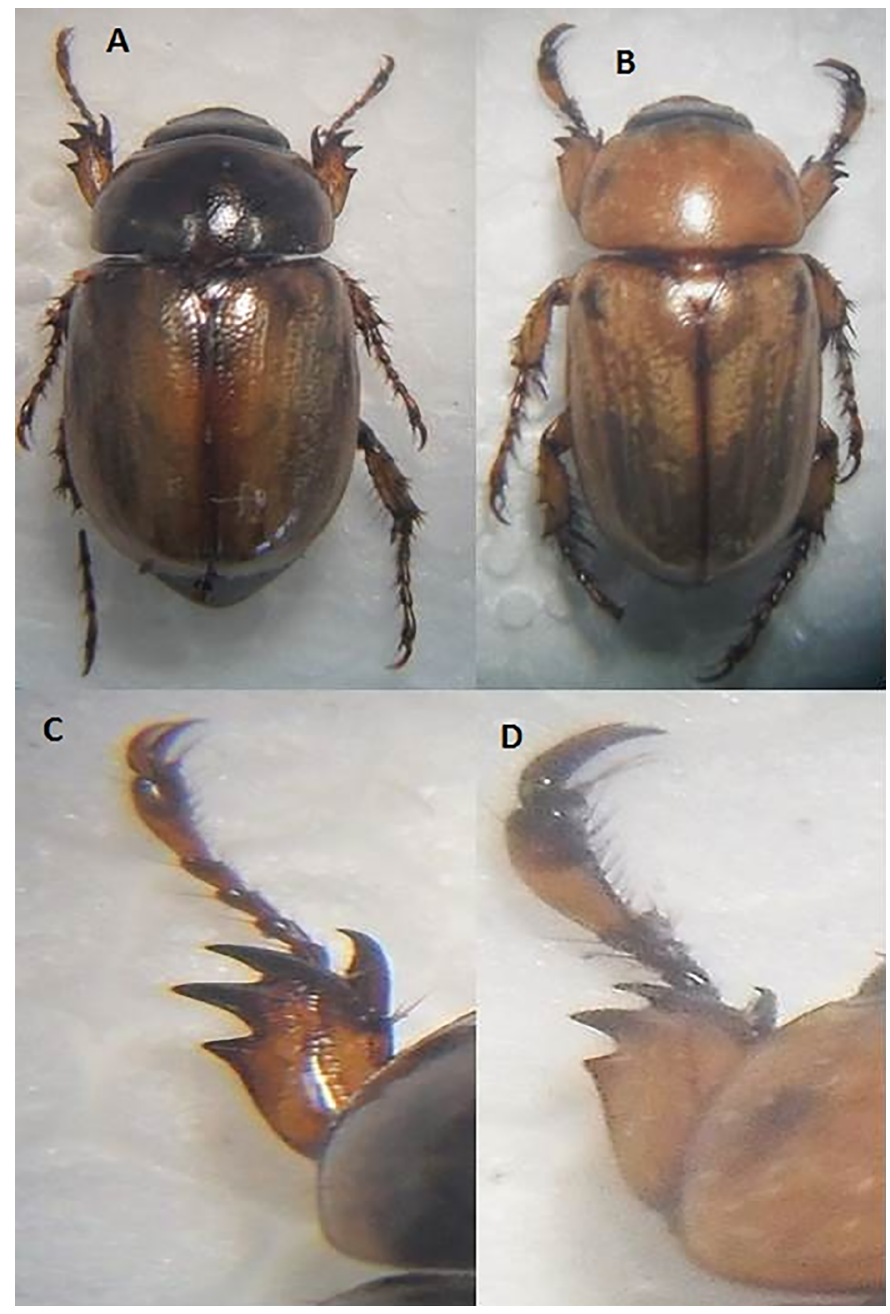

Figure 1. Cyclocephala putrida Burmeister,1847. A-B) male and female habitus, dorsal; $\mathrm{C}-\mathrm{D}$ ) male and female protarsus.

The containers were checked weekly when the soil was sieved to egg separation. After removed, the eggs were individualized and placed in other $250 \mathrm{~mL}$ plastic containers one-third filled whit soil, which were maintained in a climatized chamber $\left(26 \pm 1^{\circ} \mathrm{C}\right.$ and 12 hours scotophase). 
Each newly hatched larva was transferred to a $250 \mathrm{~mL}$ plastic container with soil and $U$. decumbens seedlings. Cranium width and body total length were weekly measured (Figure 2).

Flight activity was observed from February 2 to 27, and data were transformed into $\sqrt{x+1}$ and submitted to analysis of variance (ANOVA). Means were grouped and compared by the Scott-Knott test $(\mathrm{p}<0.05)$ using SISVAR software. Data on average temperature $\left({ }^{\circ} \mathrm{C}\right)$, precipitation $(\mathrm{mm})$, and solar radiation $\left(\mathrm{kJ} / \mathrm{m}^{2}\right)$ in Cassilândia, were obtained from the Instituto National de Meteorologia (INMET).

The study of antennal sensilla was based on antennal clava of 10 dissected specimens. Antennal segments were formerly treated in a $10 \%$ potassium hydroxide solution at $80^{\circ} \mathrm{C}$ for 60 minutes. The pieces were then successively washed in distilled water, $70 \%$ ethanol, $80 \%$ ethanol, and 90\% ethanol, respectively (Romero-Lópes et al. 2010). Images were taken by a scanning electron microscope (model JSM 5410) at the Laboratório de Microscopia Eletrônica of the Universidade Estadual Paulista, campus of Jaboticabal, state of São Paulo, Brazil.
Part of dissected lamellae was mounted on slides with Hoyer's solution (Johnson \& Triplehorn 2005) and observed under a Nikon microscope model E2000. Sensilla terminology follows Keil (1999). Meinecke (1975) was used as an alternative sensilla terminology (in brackets) to easily comparison of terms. The insects were deposited in the UEMS entomological collection, campus of Cassilândia.

\section{Results}

Mating behavior. Four hundred and fourteen (414) adults were collected in 2016, 132 in January and 282 in February, which indicates a short swarming period. From 18:00 to 19:00 $\mathrm{h}$ the brightness decreased from $131.8 \mathrm{KJ} / \mathrm{m}^{2}$ to 0 , beetles flew from dusk till dawn (from 18:00 to 6:00 of the next day), and swarm activity was high at nightfall (from 20:00 to 22:00 h). Temperature ranged from $28.5{ }^{\circ} \mathrm{C}$ to $23{ }^{\circ} \mathrm{C}$ during the flight (from 18:00 to 6:00 of the next day; Figure 3 ).

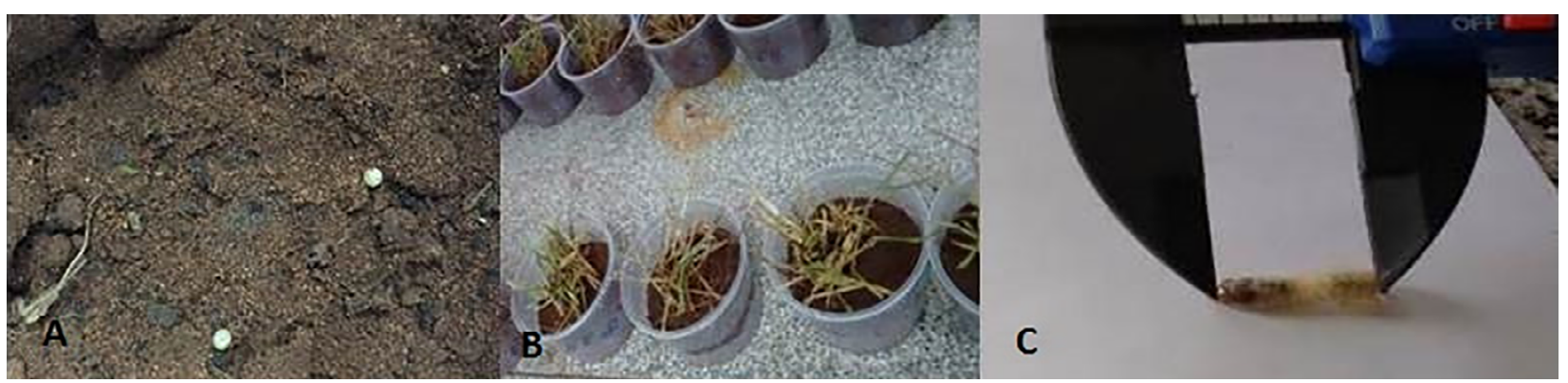

Figure 2. Cyclocephala putrida Burmeister, 1847. A) Eggs, B) Larvae in containers with soil and seedlings of Urochloa decumbens. C) measurement of larvae.
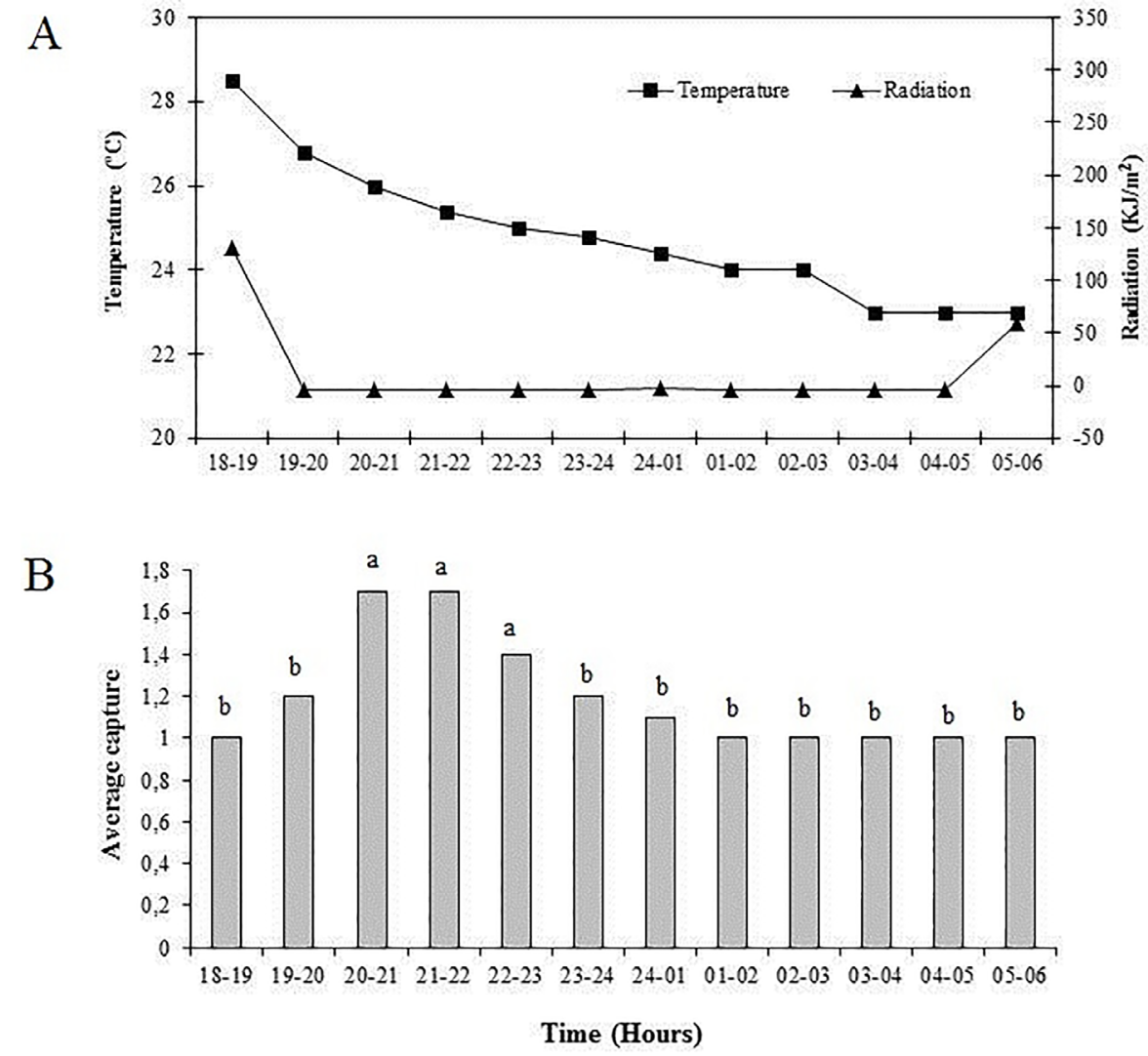

Figure 3. Radiation $\left(\mathrm{kJ} / \mathrm{m}^{2}\right)$ and average temperature $\left({ }^{\circ} \mathrm{C}\right)$ obtained from the weather station (INMET) in Cassilândia, MS, Brazil, from 2 to 27 February 2016 . A). Adults of Cyclocephala putrida collected with a light trap in the same period. B) Bars with the same letter are not statistically different (P<0.05, Scott-Knott test). 
Adults remained buried in the soil during the day and started flying from 18:00 onwards. After leaving the soil, the beetles flew for $12.6 \pm 1.86 \mathrm{~min}(11-15)$ when landed on plants for feeding and mating. Then, they started walking while their antennae kept moving and lamellae remained open. Afterwards, some couples were formed (Figure 4) and mated, with antennae movement being maintained during all stages.

Six of the 30 couples formed mated. At the first stage, males walked over females from behind $(n=5)$ or side $(n=1)$ and repeatedly touched female pygidium or apex of elytra with their antennae and protarsi. After, males climbed on females dorsum $(n=6)$ using their protarsal claws to seize females, remaining in such position for $0.55 \pm 0.22 \mathrm{~min}(0.39$ $1.0)$. Sometimes, female refused the male for mating $(n=4)$ and walked away from it (Figure 4). If accepted by the female $(n=6)$, the male griped the female elytra, using all six legs. Then, rhythmical movements were observed in the male abdomen while its aedeagus was exposed, and the copulation began.

The copula lasted $7.5 \pm 1.87 \mathrm{~min}(6-10)$ and occurred from 00:00 to 01:00 h. During the process, females stood still $(\mathrm{n}=6)$ and copulate only once. After copulation, males climbed off females and retracted their aedeagus, and then the pair quickly separated from each other. This final step lasted $7 \pm 0.31 \mathrm{sec}(5-12)$.

Antennal sensilla (Table 1). The entire outer surface of the antennal clava is covered by sensilla chaetica (long and short setae) and sensilla trichodea (minute setae, Figure 5), which were identified mainly as tactile (mechanoreceptors) but also as gustatory (contact chemoreceptors) sensilla (Keil 1999). Whereas the inner surface of clava (the lamellar side in contact with another lamella when the clava is close) was observed covered by sensilla ampullacea, basiconica, coeloconica, and placodea.

Sensilla ampullacea were identified as pores on the surface of the lamella. In Hymenoptera (Insecta), antennal pores were identified as $\mathrm{CO}_{2}$ receptors (Keil 1999); therefore, their function in scarab beetle need to be checked. Sensilla basiconica were identified as type I (Meinecke 1975: L4) and resembles minute setae enclosed in a depressed pit, with the apex projected over pit limits. Two types of sensilla coeloconica were observed, and both are ovoid and enclosed into a depressed pit, the type I (Meinecke 1975: L1) had a pointed apex and the type II (Meinecke 1975: L2) had blunt apex.

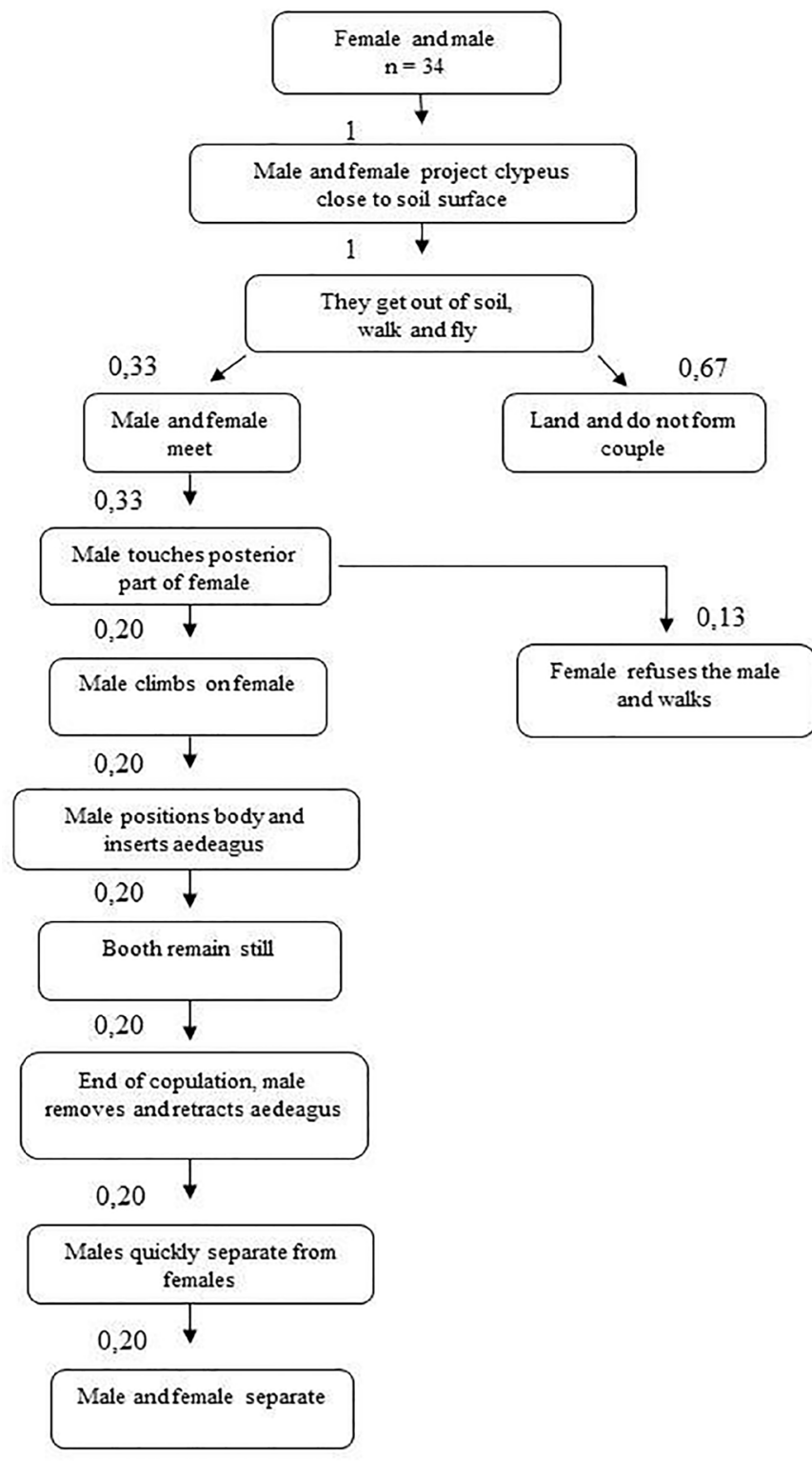

Figure 4. Ethogram of the mating behaviour of Cyclocephala putrida, Burmeister, 1847 in the laboratory.

Table 1. Sensilla of antennal lamella of Cyclocepha putrida.

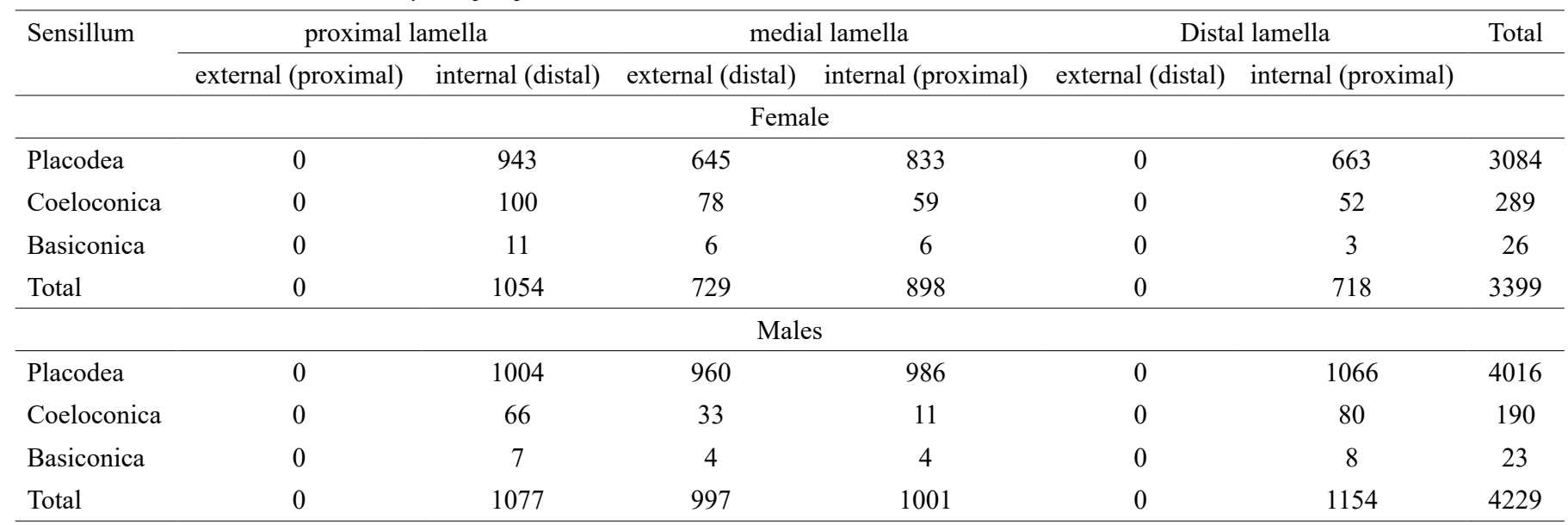



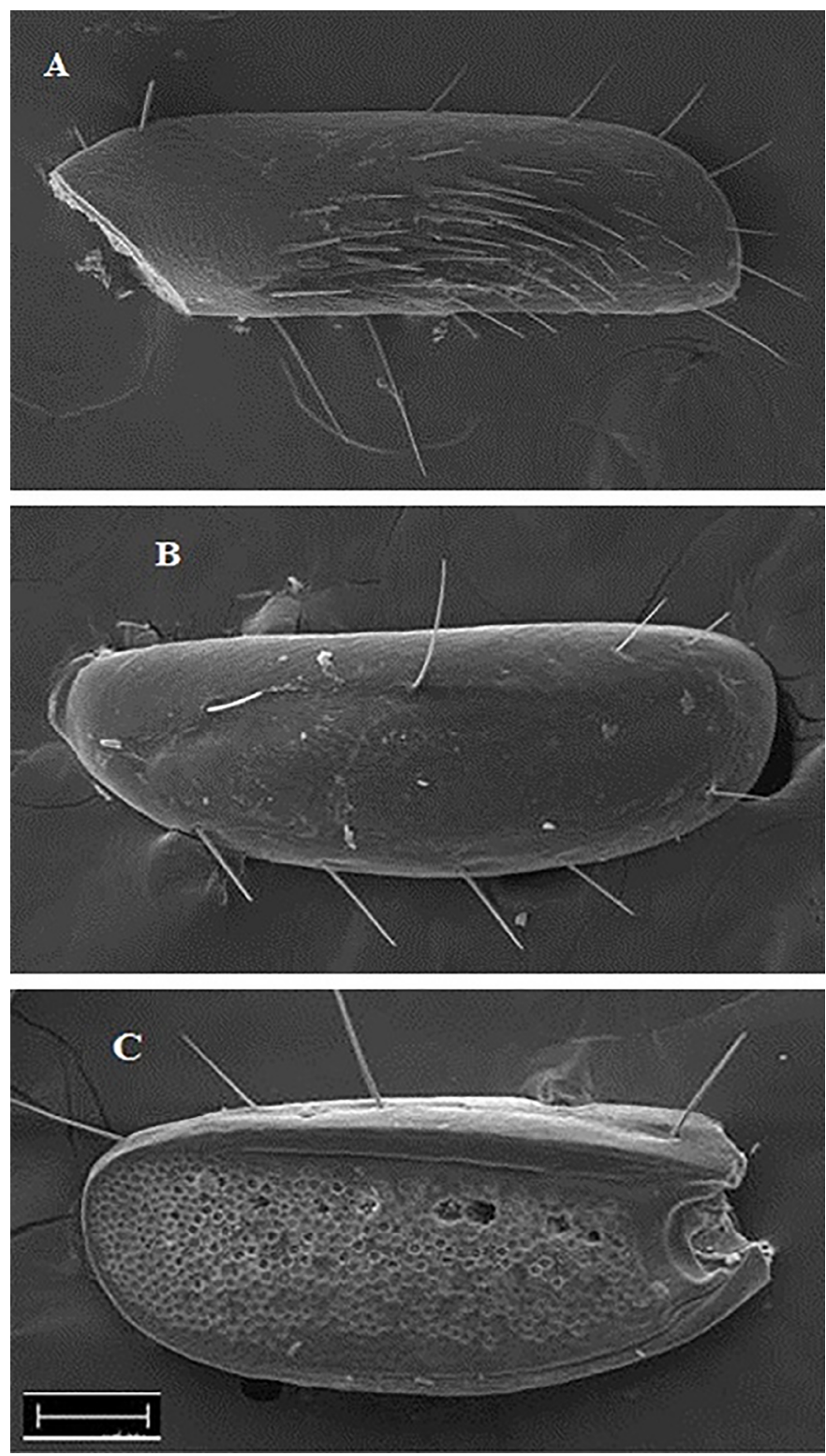

Figure 5. Cyclocephala putrida, Burmeister, 1847, antennae. A) proximal lamella, external (proximal side), B) distal lamella, external (distal side), C) medial lamella, external (distal side). Scale: 100 micrometers.

Three types of sensilla placodea are present: type I (Meinecke 1975: G2) is a plate surrounded by a ditch, the surface is irregularly reticulate and has mean diameter of $7.01 \mathrm{~m} \mu$ (3.3-10.0); type II (Meinecke 1975: G1) is similar to type I but with a smooth surface and mean diameter of $6.18 \mathrm{m \mu}$ (3.8910.0); type III (Meinecke 1975: J4) is almost smooth and the peripherical ditch is absent, mean diameter of $9.64 \mathrm{~m} \mu$ (8.33-10.0) (Figure 6).
Females have a total of 3399 sensilla in lamellae, of which 3084 $(90.7 \%)$ are sensilla placodea, $289(8.5 \%)$ are sensilla coeloconica, and $26(0.8 \%)$ are sensilla basiconica. Males have a total of 4229 sensilla, of which $4016(95.0 \%)$ are sensilla placodea, 190 (4.5\%) sensilla coeloconica, and $23(0.5 \%)$ sensilla basiconica. Both sexes have a sparse amount of sensilla ampullacea in inner clava surface.

Life cycle. In the laboratory, 22 eggs were obtained in February and 14 eggs in March. The eggs showed $100 \%$ viability (Table 2). The mean duration of egg stage was 16.0 days, first-instar larvae 16.0 days, second-instar larvae 48.3 days, third-instar larvae 165.3 days, and pupae 24 days. The first and second instars showed 80.5 and $60 \%$ viability, respectively. The initial development stages had lower viability, as they are the most sensitive during the larval phase. The mean period between egg deposition and adult emergence was 271.5 days, and viability was $41.6 \%$. Cranium width of first-instar larvae was $1.3 \mathrm{~mm}$, of second-instar larvae was $2.4 \mathrm{~mm}$, and of third-instar was $4.17 \mathrm{~mm}$. The body length of first-instar larvae was $4.4 \mathrm{~mm}$, of second-instar larvae was $7 \mathrm{~mm}$, and of third-instar larvae was $15.91 \mathrm{~mm}$. The third-instar larvae had a light grey colour that changed to white when pre-pupal stages started. Pre-pupae stop eating and make pupa chamber, possibly with aid of saliva or moist soil, manipulated with mouth appendages.

\section{Discussion}

Adults of C. putrida occurred in the field from January to February, as with C. paraguayensis found by Riehs (2006) in South of Brazil, but different from C. melanocephala, C.tucumana, C. verticalis, and others, which occur at beginning of rainy season, in September and October (Rodrigues et al. 2010, Nogueira et al. 2013). The occurrence patterns of some Cyclocephala species may be a strategy to avoid competition, but this hypothesis needs to be checked further.

Field observation showed that $C$. putrida start to flight at dusk, as other Cyclocephala species, as C. verticalis (Rodrigues et al. 2010, Barbosa \& Rodrigues 2016), and other phytophagous Scarabaeidae, as Anomala testaceipennis Burmeister, 1856 (Rutelinae) (Rodrigues et al. 2014).

In the laboratory, adults started swarming at 00:00 $\mathrm{h}$ and copula started at 1:00 h. Adults of C. verticalis, when coupled in the laboratory, started copulating regardless of the day (Rodrigues et al. 2010).

Mating of $C$. putrida encompassed several stages, including coming out of the soil, start walking, swarming, forming couples, selecting females, and copulating. This process is quite similar to that observed in other Cyclocephala species such as C. melanocephala, C. testaceipennis, and C. verticalis (Rodrigues et al. 2014, 2018, Barbosa \& Rodrigues 2016). Female selection in Scarabaeidae may be related to the recognition of male sexual maturity as in Canthon cyanellus cyanellus (LeConte, 1859) (Fávila 1988) and C. verticalis (Barbosa \& Rodrigues 2016), and is might be intermediated by chemical communication (see Rodrigues et al. 2019).

Table 2. Stages and instar development to Cyclocephala putrida.

\begin{tabular}{lcccc}
\hline stage or instar & mean duration (days) & variation (days) & number of repetitions & viability (percent) \\
\hline egg & $16.0+1.03$ & $15-18$ & 36 & 100 \\
first-instar larva & $16.0+1.03$ & $15-18$ & 29 & 80.5 \\
second-instar larva & $48.3+3.56$ & $45-54$ & 18 & 62 \\
third-instar larva & $165.3+4.81$ & $150-180$ & 18 & 100 \\
pupae & $24.0+1.56$ & $20-28$ & 16 & 88.9 \\
egg to adult & $271.5+19.28$ & $245-298$ & 15 & 41.6 \\
\hline
\end{tabular}


At the beginning of mating behavior, adults showed active movements of antennae and lamellae, probably for detection of pheromones released by other specimens. Some studies with Scarabaeidae have found that lamellar sensilla are involved in the detection of sexual pheromones, and these sensilla are more abundant in males than in females (Romero-López et al. 2004, Tanaka et al. 2006, Mutis et al. 2014). Also, males of C. putrida had more sensilla than females. Sensilla placodea was predominant in males and females of this species, while sensilla coeloconica and sensilla basiconica occurred in smaller quantities. Such dominance of sensilla placodea was also found in other Dynastinae species such as Oryctes rhinoceros (Linnaeus, 1758) (Renou et al. 1998), and in other phytophagous subfamilies such as Anomala iconstans Burmeister, 1844 (Rutelinae, Rodrigues et al. 2019). Larsson et al. (2001) studied the antennal sensilla of Anomala cuprea (Hope, 1839) and concluded that the outer sensilla placodea are responsible to detecting sexual pheromones while the inner ones are responsible for detecting plant volatiles.
The predominance of sensilla placodea may be related to important roles in detection food resources and adult info-chemicals (sexual or aggregative).

Concerning the life cycle of $C$. putrida, the period between egg deposition and adult emergence was on average of 271.5 days, so it could be considered a long life beetle if compared to other Cyclocephala species. Long cycles were also noticed for C. melanocephala (113 days) (Nogueira et al. 2013), C. paraguayensis (171 days) (Albuquerque et al. 2014), C. tucumana (211.2 days) (Nogueira et al. 2013), C. verticalis (228.6 days) (Rodrigues et al. 2010) (Table 3). The embryonic phase of $C$. putrida had a similar length to that other Cyclocephala species; however, the first instar lasted 16 days, a period shorter than in the other species (Table 3). The second and third instars of $C$. putrida lasted, in days, shorter than did C. tucumana, which lasted 66.1 and 176.8 days, respectively (Table 3 ). And its pupal phase was also shorter than $C$. celata (Table 3 ).

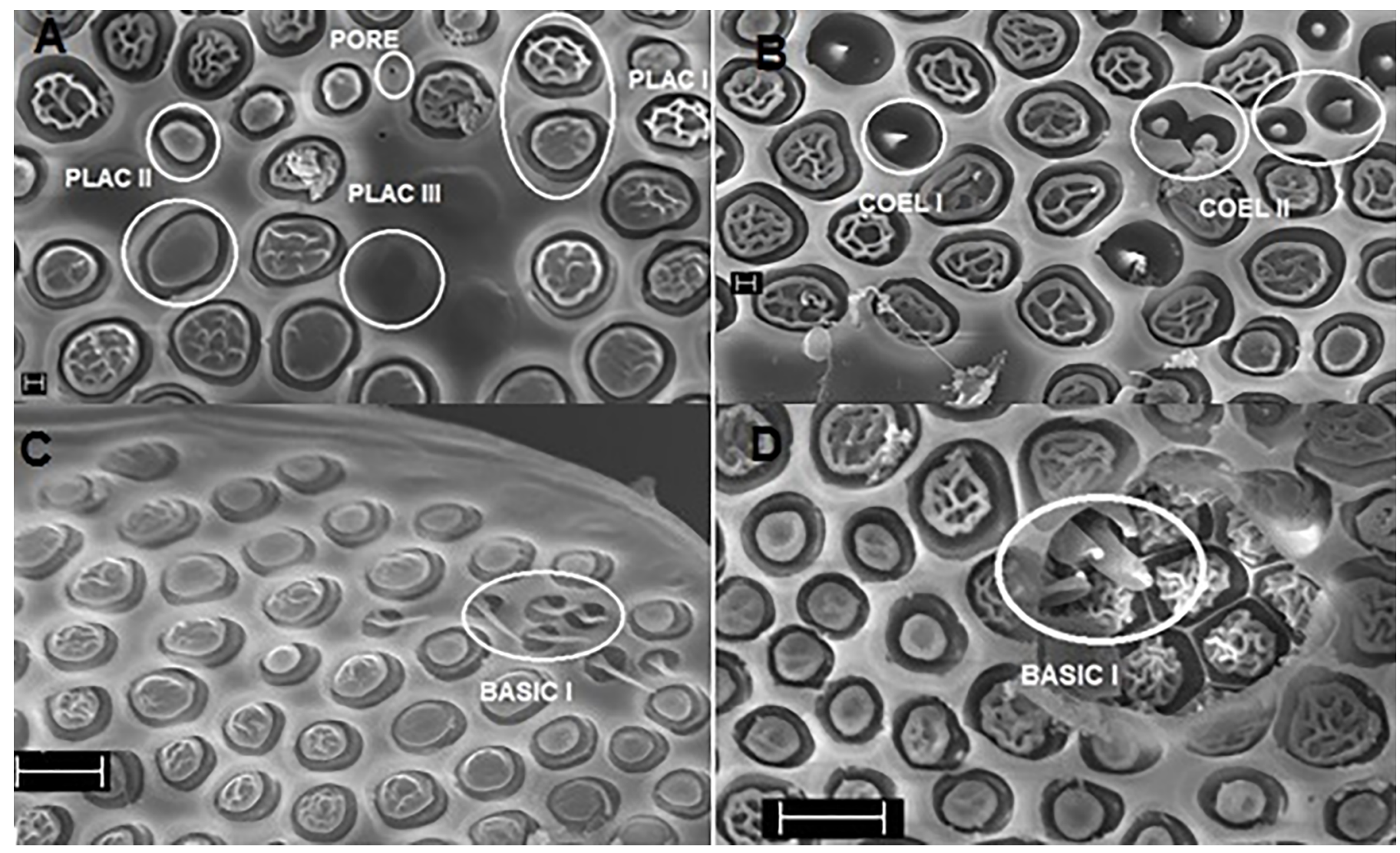

Figure 6. Cyclocephala putrida, Burmeister, 1847, antennal sensilla. A) Sensilla placodea type I, II, and III (PLAC I-III), and sensilla ampullacea (PORE). B) Sensilla coeloconica type I and II (COEL I-II). C-D) Sensilla basoconica type I (BASIC I). A-B) Scale 2 micrometers. C-D) Scale: 10 micrometers.

Table 3. Biological data of Cyclocephala species.

\begin{tabular}{cccccccc}
\hline Cyclocephala species & \multicolumn{4}{c}{ Duration (days) } & \multicolumn{3}{c}{ reference } \\
\cline { 2 - 6 } & Egg & Fist instar & Second instar & Third instr & Pupae & Egg to adult & \\
\hline C. melanocephala & 17.8 & 22.3 & 21.0 & 38.3 & 13.3 & 113.0 & Nogueira et al. 2013 \\
C. paraguayensis & 18.7 & 42.2 & 20.0 & 75.3 & 11.4 & 171.0 & Albuquerque et al. 2014 \\
C. tucumana & 14.7 & 47.7 & 66.1 & 176.8 & 15.0 & 211.2 & Nogueira et al. 2013 \\
C. verticalis & 17.2 & 22.0 & 23.7 & 150.8 & 14.8 & 228.6 & Rodrigues et al. 2010 \\
C. celata & 13.9 & 22.0 & 26.2 & 68.3 & 38.0 & 164.0 & Souza et al. 2014 \\
\hline
\end{tabular}


Regarding the immatures, C. putrida larvae fed soil organic matter, so the species is not a potential pest to cultivated plants. White grubs had similar behavior compared to other Cyclocephala species. Its active third instar is yellowish-white, while prepupa is white and builds a pupal chamber, just as observed in C. celata and C. distincta (Souza et al. 2014, 2015).

\section{Acknowledgments}

This work was supported by Fundação de Apoio ao Desenvolvimento do Ensino, Ciência e Tecnologia do Estado de Mato Grosso do Sul (FUNDECT) (Process n. 217/2016). To the Instituto Nacional de Ciência e Tecnologia (INCT) Semioquímicos na Agricultura (Fapesp 2014/50871-0) and CNPq (465511/2014-7) for the financial support. Juares Fuhrmann thanks Sônia A. Casari (Museu de Zoologia da Universidade de São Paulo) by suppervision.

\section{Author Contribution}

Fabiola Gonzaga Saldanha: Contribution to data collection; Contribution to data analysis and interpretation; Contribution to manuscript preparation; Contribution to critical revision, adding intellectual content.

Sérgio Roberto Rodrigues: Contribution to data collection; Contribution to data analysis and interpretation; Contribution to manuscript preparation; Contribution to critical revision, adding intellectual content.

Juares Fuhrmann: Contribution in the analysis and interpretation of data, also assisting in article revision, adding intellectual content.

Ricardo Aparecido Amaro: Contribution to data collection; Contribution to data analysis and interpretation; Contribution to manuscript preparation; Contribution to critical revision.

\section{Conflicts of interest}

The authors declare that they have no conflict of interest related to the publication of this manuscript.

\section{References}

ALBUQUERQUE, L.S.C., SOUZA, T.B., MAIA, A.C.D. \& IANNUZZI, L. 2014. New biological and immature morphological records of the masked chafer, Cyclocephala paraguayensis. J. Insect Sc. 14(101): 1-11. https:doi. org/10.1673/031.014.101

BAKER, G.T. \& MONROE, W.A. 2005. Sensilla on the adult and larval antennae of Cotinis nitida (Coleoptera: Scarabaeidae). Microsc. Microanal. 11(Suppl 2): 170-171. https://doi.org/10.1017/S1431927605500448

BARBOSA, C.A.F. \& RODRIGUES, S.R. 2016. Comportamento de cópula em Cyclocephala verticalis Burmeister (Coleoptera: Scarabaeidae) Entomobrasilis 9(3): 158-162. https://doi.org/10.12741/ebrasilis.v9i3.581

BONIVARDO, S.L., MARTINEZ, A.N., PERSSI MAGNA, G. \& PÉREZ SUAREZ, A. 2015. Relevamiento de escarabeidos (Insecta, Coleoptera) em pastizal natural, pasto llorón y maiz, em el este de la província de San Luis (Argentina). Revista FAVE, Ciencias Agrarias 14(2): 1-8. https://doi. org/10.14409/fa.v14i2.5718

CAMARGO, A.J.A. \& AMABILE, R.F. 2001. Identificação das principais pragas do girassol na região centro-oeste. Embrapa Cerrados, Com. Técnico 50: 4 p. http://ainfo.cnptia.embrapa.br/digital/bitstream/CPAC2010/20961/1/comtec-50.pdf
CHERMAN, M.A., MORÓN, M.A., DAL PRÁ, E., VALMORBIDA, I. \& GUEDES, J.V.C. 2014. Ecological characterization of white grub (Coleoptera: Melolonthidae) community in cultivated and noncultivated fields. Neotrop. Entomol. 43(3): 282-288. https://doi.org/10.1007/s13744-014-0214-0

DIAS, B.M.R. \& RODRIGUES, S.R. 2018. Floral association of adult Cyclocephala tucumana Brethes and Cyclocephala melanocephala (Fabricius) with passion flowers (Passiflora edulis Sims). Entomobrasilis 11(2): 144-146. https://doi.org/10.12741/ebrasilis.v11i2.738

DUCHINI, P.G., ECHEVERRIA, J.R., AMÉRICO, L.F., GUZATTI, G.C., CHERMAN, M.A. \& SBRISSIA, A.F. 2017. White grubs (Cyclocephala flavipennis) damaging perennial winter pastures in the south region of Brazil. Ciência Rural, 47(5): e20160662, 4p. http://dx.doi.org/10.1590/0103$8478 \mathrm{cr} 20160662$

FACUNDO, H.T., LINN, C.E., VILLANI, M.G. \& ROELOFS, W.L. 1999 Emergence, mating, and postmating behaviors of the oriental beetle (Coleoptera: Scarabaeidae). J. Insect Behav. 12: 175-192. https://doi. org/10.1023/A:1020910732029

FÁVILA, M.E. 1988. Comportamento durante o período de maturação gonádica em um besouro de roedor (Coleoptera: Scarabaeidae; Scarabaeinae). Fol. Entomol. Mex.76: 55-64.

FERREIRA, K.R., GOMES, E.S. \& RODRIGUES, S.R. 2016. Biological aspects and mating behavior in Leucothyreus albopilosus (Coleoptera). Rev. Biol. Trop. 64(2): 547-557. http://dx.doi.org/10.15517/rbt.v64I2.1924

GOTTSBERGER, G., SILBERBAUER-GOTTSBERGER, I., SEYMOUR, R.S. \& DÖTTERL, S. 2012. Pollination ecology of Magnolia ovata may explain the overall large flower size of the genus. Flora 207: 107-118. https:// doi.org/10.1016/j.flora.2011.11.003

GROSSI, P.C. \& VAZ-de-MELLO, F.Z. 2019. Melolonthidae in Catálogo Taxonômico da Fauna do Brasil. Avaliable in: $<$ http://fauna.jbrj.gov.br/fauna/ faunadobrasil/145460> Accessed in 26 May 2020.

JOHNSON, N.F. \& TRIPLEHORN, C.A. 2005. Borror and DeLong's Introduction to the Study of Insects, 7th edition. Belmont, Thomson Learning, Belmont.

KEIL, T.A. 1999. Chapter 1. Morphology and development of the peripheral olfactory organs. In Insect olfaction (B Hansson, ed.). Springer, Berlin, p. 6-44.

KIM, J.Y. \& LEAL, W.S. 2000. Ultrastructure of pheromone-detecting sensillum placodeum of the Japanese beetle, Popillia japonica Newmann (Coleoptera: Scarabaeidae). Arthrop. Struc. Develop. 29: 121-128. https:// doi.org/10.1016/s1467-8039(00)00022-0

LARSSON, M.C., LEAL, W.S. \& HANSSON, B.S. 2001. Olfactory receptor neurons detecting plant odours and male volatiles in Anomala cuprea beetles (Coleoptera: Scarabaeidae). J. Insect Physiol. 47(9): 1065-1076. https://doi. org/10.1016/S0022-1910(01)00087-7

LEAL, W.S. \& MOCHIZUKI, F. 1993. Sex pheromone reception in the scarab beetle Anomala cuprea: enantiomeric discrimination by sensilla placodea. Naturwissenschaften 80: 278-281.

MAIA, A.C.D., GIBERNAU, M., CARVALHO, A.T., GONÇALVES, E.G. \& SCHLINDWEIN, C. 2013. The cowl does not make the monk: scarab beetle pollination of the neotropical aroid Taccarum ulei (Araceae: Spathicarpeae). Biol. J. Linn. Soc. 108: 22-34. https://doi.org/10.1111/j.1095-8312.2012.01985.x

MEINECKE, C.C. 1975. Riechsensillen und Systematik der Lamellicornia (Insecta, Coleoptera). Zoomorphologie 82: 1-42.

MOORE, M.R. \& JAMESON, M.L. 2013. Floral associations of cyclocephaline scarab beetles. J. Insect Sc. 13(100): 1-43. https://doi. org $/ 10.1673 / 031.013 .10001$

MUTIS, A., PALMA, R., PARRA, L., ALVEAR, M., ISAACS, R., MORÓN, M. \& QUIROZ, A. 2014. Morphology and distribution of sensilla on the antennae of Hylamorpha elegans Burmeister (Coleoptera: Scarabaeidae). Neotrop. Entomol. 43: 260-265. https://doi.org/10.1007/s13744-014-0208-y

NOGUEIRA, G.A.L., RODRIGUES, S.R. \& TIAGO, E.F. 2013. Biological aspects of Cyclocephala tucumana Brethes, 1904 and Cyclocephala melanocephala (Fabricius, 1775) (Coleoptera: Scarabaeidae). Biota Neotrop. 13(1): 86-90. http://www.biotaneotropica.org.br/v13n1/en/ abstract?article+bn01713012013 
OLIVEIRA, H.N. \& ÁVILA, C.J. 2011. Ocorrência de Cyclocephala forsteri em Acrocomia aculeata. Pesq. Agrop. Trop. 41(2): 293-295. https://doi. org/10.5216/pat.v41i2.8769

RENOU, M., TAUBAN, D. \& MORIN, J.P. 1998. Structure and function of antennal pore plate sensilla of Oryctes rhinoceros (L.) (Coleoptera: Dynastinae). Int. J. Insect Morphol. Embryol. 27(3): 227-233. https://doi. org/10.1016/S0020-7322(98)00014-2

RIEHS, P.J. 2006. Fenologia de algumas espécies do gênero Cyclocephala (Coleoptera, Scarabaeidae) do leste e centro-oeste do Paraná, Brasil. Rev. Ciên. Exat. e Nat. 8(2): 201-223.

RODRIGUES, S.R., BARBOSA, C.L., PUKER, A., ABOT, A.R. \& IDE, S. 2008. Occurrence, biology and behavior of Liogenys fuscus Blanchard (Insecta, Coleoptera, Scarabaeidae) in Aquidauana, Mato Grosso do Sul. Rev. Bras. Entomol. 52: 637-640. http://dx.doi.org/10.1590/S008556262008000400015

RODRIGUES, S.R., NOGUEIRA, G.A.L., ECHEVERRIA, R.R. \& OLIVEIRA, V.S. 2010. Aspectos biológicos de Cyclocephala verticalis Burmeister (Coleoptera: Scarabaeidae). Neotrop. Entomol. 39(1): 15-18. http://dx.doi.org/10.1590/S1519-566X2010000100003

RODRIGUES, S.R., GOMES, E.S. \& BENTO, J.M.S. 2014. Sexual dimorphism and mating behavior in Anomala testaceipennis. J. Insect Sc. 14(210): 1-5. http://dx.doi.org/10.1093/jisesa/ieu072

RODRIGUES, S.R., BARBOSA, C.A.F., FUHRMANN, J. \& AMARO, R.A. 2018. Mating behavior and description of immature stages of Cyclocephala melanocephala (Fabricius, 1775) (Coleoptera: Scarabaeidae: Dynastinae), identification key and remarks on known immatures of Cyclocephalini species. Rev. Bras. Entomol. 62(3): 205-219. https://doi.org/10.1016/j. rbe.2018.07.001

RODRIGUES, S.R., FUHRMANN, J. \& AMARO, R.A. 2019. Aspects of mating behavior and antennal sensilla in Anomala inconstans Burmeister, 1844 (Coleoptera: Scarabaeidae: Rutelinae). Biota Neotrop.19(3): e20180664, 7p. http://dx.doi.org/10.1590/1676-0611-BN-2018-0664.
ROMERO-LÓPEZ, A.A., ARZUFFI, R., VALDEZ, J., MORÓN, M.A., CASTREJÓN-GÓMEZ, V. \& VILLALOBOS, F.J. 2004. Sensory organs in the antennae of Phyllophaga obsoleta (Coleoptera: Melolonthidae). Ann. Entomol. Soc. Am. 97: 1306-1313. https://doi.org/10.1603/00138746(2004)097[1306:SOITAO]2.0.CO;2

ROMERO-LÓPEZ, A.A., MORÓN, M.A. \& VALDEZ, J. 2010. Sexual dimorphism in antennal receptors of Phyllophaga ravida Blanchard (Coleoptera: Scarabaeoidea: Melolonthidae). Neotrop. Entomol. 39:957966. http://dx.doi.org/10.1590/S1519-566X2010000600018

SANTOS, V. \& ÁVILA, C.J. 2007. Aspectos bioecológicos de Cyclocephala forsteri Endrodi, 1963 (Coleoptera: Melolonthidae) no estado de Mato Grosso do Sul. Rev. Agric. 82(3): 298-303.

SILVA, W.R \& SAZIMA, M. 1995. Hawkmoth pollination in Cereus peruvianus, a columnar cactos from southeastern Brazil. Flora 190: 339-343.

SOUZA, T.B., MAIA, A.C.D., SCHLINDWEIN, C., ALBUQUERQUE, L.S.C. \& IANNUZZI, L. 2014. The life of Cyclocephala celata Dechambre, 1980 (Coleoptera: Scarabaeidae: Dynastinae) in captivity with descriptions of the immature stages. J. Nat. Hist. 275-283. https://doi.org/10.1080/002 22933.2013.791886

SOUZA, T.B., MAIA, A.C.D., ALBUQUERQUE, C.M.R. \& IANNUZZI, L. 2015. Biology and management of the masked chafer Cyclocephala distincta Burmeister (Melolonthidae, Dynastinae, Cyclocephalini). Rev. Bras. Entomol. 59(1): 37-42. http://dx.doi.org/10.1016/j.rbe.2015.02.004

TANAKA, S., YUKUHIRO, F. \& WAKAMURA, S. 2006. Sexual dimorphism in body dimensions and antennal sensilla in the shite grub beetle, Dasylepida ishigakiensis (Coleoptera, Scarabaeidae). Appl. Entomol. Zool. 41(3): 455461. https://doi.org/10.1303/aez.2006.455

Received: 07/02/2020

Revised: $25 / 05 / 2020$

Accepted: $30 / 07 / 2020$

Published online: 26/08/2020 